\title{
Applied learning and teaching transformations through project-based action learning in an International Business Management programme
}

\author{
Chan KC ${ }^{1}$, Rudolph J. ${ }^{2}$, Tan S. ${ }^{3}$,
}

\begin{abstract}
This paper expounds on applied learning and teaching transformations through project-based action learning for students' self-awareness and effective competence development. After providing some background to the Indonesian university where the research took place and a brief review of the literature, we describe the methodology. The article is based on longitudinal action research over 13 years that used a mixed-methods survey that generated multiple testimonials that were assessed via thematic content analysis. Six phases of learning innovations are discerned: Awareness, alignment, action, adoption, assurance and anticipation. These phases of the transformational process also provide the structure for the findings and discussion section. To succeed, international business management graduates have to continuously strategise, implement, and incorporate a closed-loop feedback system to track and manage individual progress with an action learning balanced scorecard. As wholebrain learners, the pursuit of knowledge must be transformed into a value-added advantage in four types of interconnected and interdependent power.
\end{abstract}

Keywords: accelerated learning, action learning, case study, Indonesia, innovation, project management, strategy implementation, transformation, whole-brain learners.

\footnotetext{
1 Visiting Professor, Department of Economics, Petra Christian University, Surabaya, Indonesia, email: wholistic_kcchan@singnet.com.sg

${ }^{2}$ Head of Research \& Senior Lecturer, Kaplan Higher Education Singapore, email: jurgen.rudolph@kaplan.com

${ }^{3}$ Research Assistant, Kaplan Higher Education Singapore, email: shannontan@kaplan.com
} 


\section{INTRODUCTION}

This paper expounds on applied learning and teaching transformations through project-based action learning for students' self-awareness and effective competence development. The purpose of this paper is to track the lead author's two-decade experience in teaching a series of International Business Management (IBM) modules at an Indonesian university, and its effects on students' professional life trajectories after having completed their Bachelor's studies, especially in terms of their career. The overarching research question is:

Has the students' learning during the series of IBM modules benefited them in terms of employability and becoming critical, holistic thinkers?

After a brief literature review and the provision of some background information, the research methodology is described. The longitudinal action research incorporated a mixedmethods research survey and a thematic content analysis of graduate testimonials.

At present, higher education (HE) is undergoing rapid transformation due to Covid-19 (Crawford et al., 2020, Bonk et al., 2020; Butler-Henderson et al., 2020, 2021) as well as dealing with internationalization (De Wit et al., 2015), the "data revolution" (von Hippel \& Hofflinger, 2021), and the pursuit of a fairer higher education sector. Within this fastchanging macro-environmental context, there is a clear rationale and background for the use of project-based learning in higher education. Nieto-Rodriguez (2016) espoused that projects are key to optimise applied teaching and learning. The findings and discussion section is structured according to the project-based action learning paradigm and the six phases of the transformation process using a private university in Surabaya, Indonesia, as a test-bed for more than a decade (from 2006 to 2018). The six phases are awareness, alignment, action, adoption, assurance and anticipation. These phases of the transformational process also provide the structure for this article which is based on longitudinal action research (that includes a survey and the thematic content analysis of testimonials). To succeed, international business management graduates have to continuously strategise, implement, and incorporate a closed-loop feedback system to track and manage individual progress with an action learning balanced scorecard. As whole-brain learners, the pursuit of knowledge must be transformed into a value-added advantage in four types of interconnected and interdependent power. 


\subsection{Background and brief literature review}

Before describing the process that students go through during their International Business Management studies at Universitas Kristen Petra (Petra Christian University, henceforth abbreviated as Petra), it is critical that we understand the university context. Knowledge about a specific context enables the potential transferability of insights to other university contexts (Slevin \& Sines, 1999). Hence, a brief introduction to Petra is in order.

Petra was founded in 1961 by Perhimpunan Pendidikan dan Pengajaran Kristen Petra (PPPK Petra), an Indonesian Christian educational foundation. It is the non-profit private university's vision to be a "caring and global university" committed to Protestant values (Top Universities, 2021). Petra is amongst the oldest and largest private Christian universities in Indonesia, situated in Surabaya, East Java, Indonesia. At present, it is a medium-sized university with an approximate annual enrolment ranging from 7,000 to 10,000 students and eight faculties (uniRank, 2021, UK Petra, 2017).

The university landscape in Indonesia - an archipelagic state with over 17,000 islands and a total population of 270 million, and the world's most populous Muslim-majority country - is complex. Amongst approximately 3,276 Indonesian universities, there are 122 public universities (Maulani \& Hamdani, 2019). Only 1,130 universities are accredited, with about 50 (amongst them, Petra) achieving the highest ' $A$ ' accreditation tier by the National Accreditation Board (UK Petra, 2017). The global rankings of Indonesian universities have been characterised as "very disappointing", with only nine Indonesian universities being indexed by QS World University Rankings (Maulani \& Hamdani, 2019, p. 142).

Whilst Petra is considered the top private university in Indonesia by some (Litamahuputty, 2015; UK Petra, 2017), it has, in recent years, consistently been ranked as a top 15 private university by the Indonesian Ministry of Education (Top Universities, 2021). Petra's IBM programme is a four-year Bachelor course in the Faculty of Business and Economics that is conducted in English rather than the national language, Bahasa Indonesia. The IBM programme is committed not only to improving the cognitive aspects of its students with special reference to the internationalisation of business but also to strengthening their integrity and shaping their professional attitude.

A Pareto analysis (popularly known as the $80 / 20$ rule) (Koch, 1999, 2014) can be applied to higher education (HE), with $80 \%$ of education being less relevant to graduates' performance in the workplace. Learning encompasses the transformation from an 'old' behaviour to a 'new' positive behaviour, which may create a knowledge advantage. Otherwise, we have not acquired actionable knowledge (see Figure 1 for the 80/20 rule). Figure 2 shows the cumulative effect of learning with new knowledge building on prior knowledge, and it becoming increasingly powerful within a learning transformation cycle. 


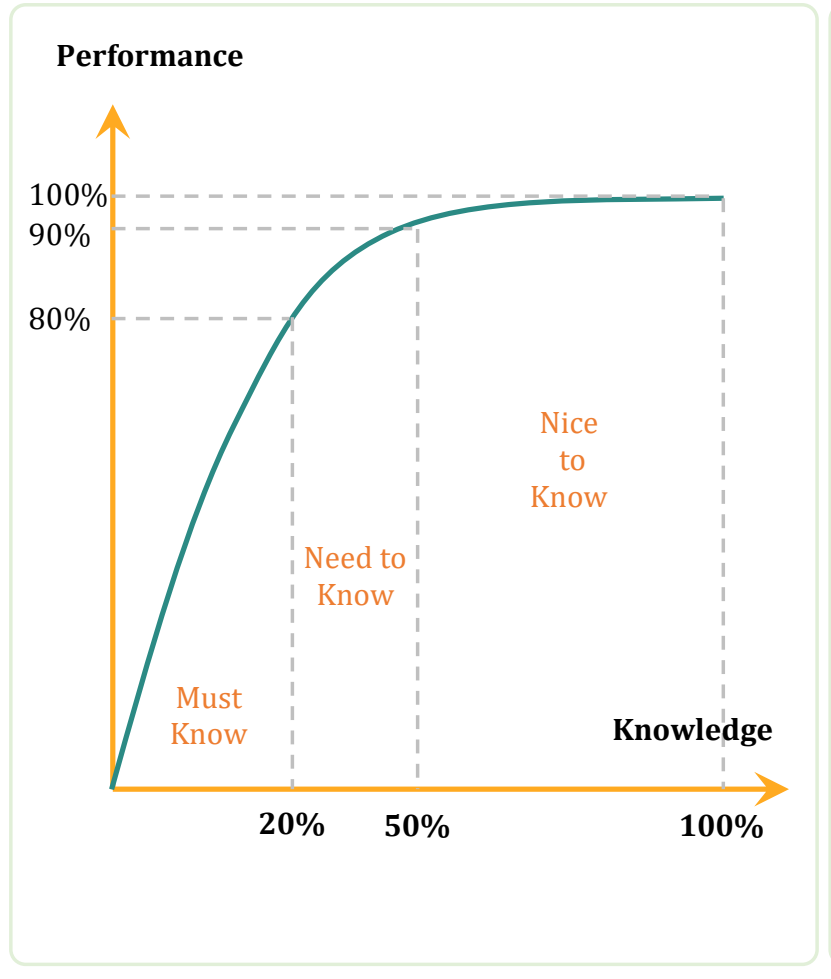

Figure 1: 80/20 rule.

\section{Knowledge/ Behaviour}

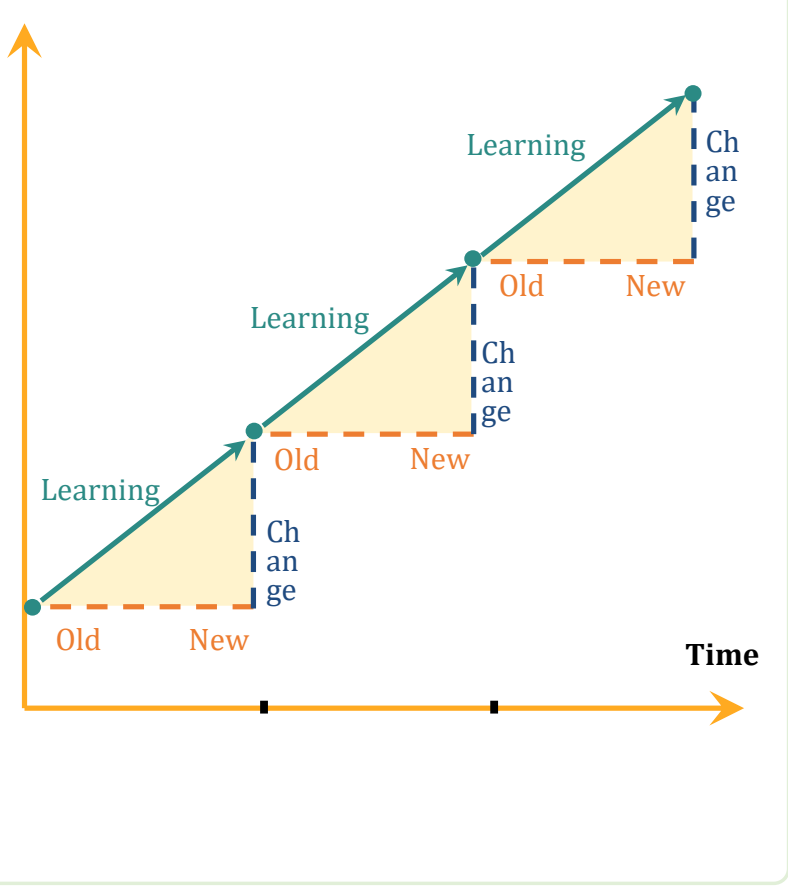

Figure 2: Learning transformation cycle.

From a holistic approach to applied learning, the next element for knowledge retention is project-based action learning (Revans, 2011; Wills, 1993; Zuber, 2017; Teare, 2018; Marquardt et al., 2018; Chan, 2017a). This is also known as workplace learning (Abraham, 2012), where $75 \%$ effectiveness can be achieved (see Figure 3 for the percentage of knowledge retention through different learning techniques). In contrast, case studies apparently are only $50 \%$ effective. Since learning by doing, or project-based learning, tends to achieve $75 \%$ effectiveness, it constitutes a powerful approach in HE. 


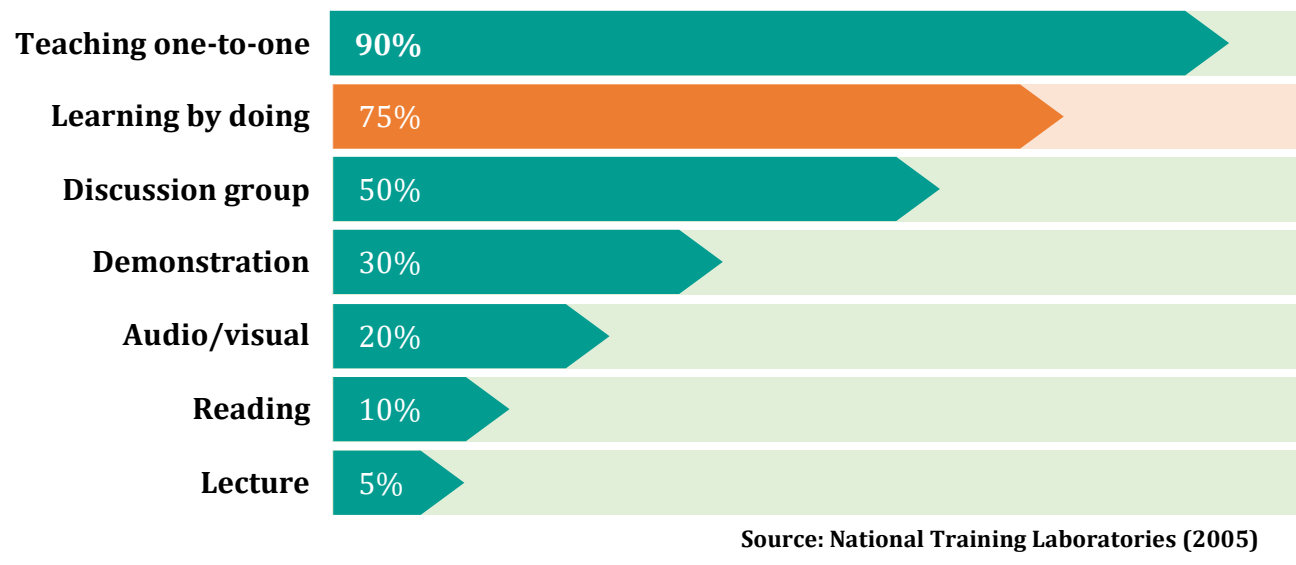

Figure 3: Percentage of knowledge retained after completion of learning.

The three-pronged approach of project-based action learning utilises:

- holistic thinking - for integration of people, process, and tools for effective planning;

- systems thinking - for successful implementation of strategy by converting it into a portfolio of prioritised programmes and projects with the right key performance indicators for effective monitoring and controlling; and

- critical thinking - for innovation of products and services to achieve faster, better, and smarter outcomes because of effective decision-making.

This approach is highly suitable for a university teaching environment. Project-based action learning is not just useful for the retention of knowledge, but aims much higher, such as for building leadership capabilities (Barkley et al., 2001). One of the suggestions of this article is to promote project management as a core competence of HE students and as a common language for non-routine work by enhancing team capacity in order to achieve synergistic effects. This could help in improving higher education institutions' capabilities for organisational transformation. As a result, the Project Management Institute (USA) revised the Project Management Body of Knowledge (PMBOK) in 2017 - the sixth edition changes the mission of project management to "Organisational Project Management." This reflects the significance of connecting strategy, business and operations for alignment and optimisation of resources for coherent objectives and results. 


\section{METHODOLOGY}

What is being described in the findings and discussion section is not something that was created from the beginning by the lead author, when he started to teach in the IBM programme in 2002 at Petra. It went through many iterations by adopting an action research approach that continued to reflect on, and incorporate, his students' feedback in constantly improving his teaching and learning approach. The lead author's educational action research approach to evaluate the different teaching strategies and learning outcomes is comparable to those of Mettetal (2002) and Gay \& Airasian (2003): it starts by identifying a research question (Has the students' learning during the series of IBM modules benefited them in terms of employability and becoming critical, holistic thinkers?) and moves through the following stages: reviewing the literature; planning a research strategy; gathering data; making sense of the data; taking actions; reviewing the results (based on student and other feedback) and continually improve.

The data were collected during the period of 2006 to 2018. A mixed-methods survey was sent via email to all alumni (hence, no sampling) of the 13 cohorts of IBM students (that start with 60 - 80 students each). The question posed to the students was:

"Would you share in a concise way, how have you benefited from learning the "Wholistic Approach' taught by Prof. KC Chan after you have graduated from Petra?"

It may be useful to note here that the term "wholistic" (Carter et al. (Eds.), 2012) is not a misspelling. The lead author conceptualises "wholistic thinking" as something that is larger than mere holistic thinking as the ability to utilise both the right brain (holistic thinking) and the left brain (systems thinking) for effective analysis (lateral thinking) resulting in effective decision-making (critical thinking).

The total population amounted to 819 students with a response rate of $31 \%$, i.e. 253 respondents. The respondents were aged 23 years and above. A precondition of the selection of these participants was that they had to have at least one year of working experience to qualify for participation in the survey. Consequently, responses that did not meet the criteria were discarded. In addition, a survey with 208 respondents was conducted in 2016 for IBM graduates who had over five years of working experience after graduation.

Using Braun and Clarke's (2006) thematic analysis method, we analysed the graduates' reflective responses. An inductive approach was employed in analysing all responses and themes were coded without trying to fit them into a pre-existing coding frame. These codes exhibited emerging patterns (Braun \& Clark, 2006). Initially, ten themes (way of thinking; perspectives; thinking critically; project management; integration; business strategies; planning; problem-solving; ideas; and decision making) were generated which encompassed several sub-themes. Through an iterative analysis, themes were then combined to develop a deeper context for recurring phenomena. We eventually arrived at three final themes - 
wholistic thinking; structured thinking, and project management skills - which will be discussed in the following section.

\section{FINDINGS AND DISCUSSION}

We now present the afore-mentioned six-phase model, consisting of awareness, alignment, action, adoption, assurance and anticipation. Survey results and a thematic analysis of graduate testimonials are presented within the section on the assurance phase. Figure 4 captures the 6As design thinking approach in understanding and constructing a module using relevant tools or templates for analysis. We exemplify the application of the model to the IBM programme.

Awareness: it is essential to ask what IBM is, why IBM is vital to a country, industry and company, and how IBM is conducted regionally, internationally, and globally.

Alignment: it is essential to use the Delta Matrix to get a better picture of the subject matter by examining the nine elements which are explained in Figure 8.

Action: it is essential to strategise, implement and operate (S-I-O) and use a balanced scorecard to monitor and control the outcome of the strategy. The output is a business strategy to be executed by the right people who know the right process for implementation and are equipped with the right tools for speed of execution. The investments for the business strategy are prioritised into a portfolio of programmes and projects for implementation. It is necessary to have an enterprise balanced scorecard to form a closed-loop feedback and control system to measure the learning and growth of the employees, the internal business processes in meeting the VUCA (volatile, uncertain, complex, and ambiguous) business environment, customer satisfaction, and sustainable financial performance.

Adoption: it is essential to achieve buy-in from the stakeholders. An effective method is to ask the Five Whys of making any change or transformation. For example: Why change? Why change now? What if we don't change? When should we change? Where should we change? "People don't resist change; they resist being changed" (Senge, 2014, p. 55).

Assurance: it is essential to improve continuously by focusing on the goal, objectives and targets, which depend on what we have set as our baseline. These goals can be short-term (up to three-year targets), mid-term (up to six-year targets), and long-term (up to ten-year targets). Meeting these goals warrants alignment with the development and cohesive planning of operations objectives.

Anticipation: it is essential to plan a risk response strategy from the awareness to assurance phases. Otherwise, there will not be enough time for risk planning for the implementation of the risk response strategy to cater for both positive risk (opportunity) and negative risk (threat). For IBM, there are four basic types of risk - market, financial, political, and cultural. 


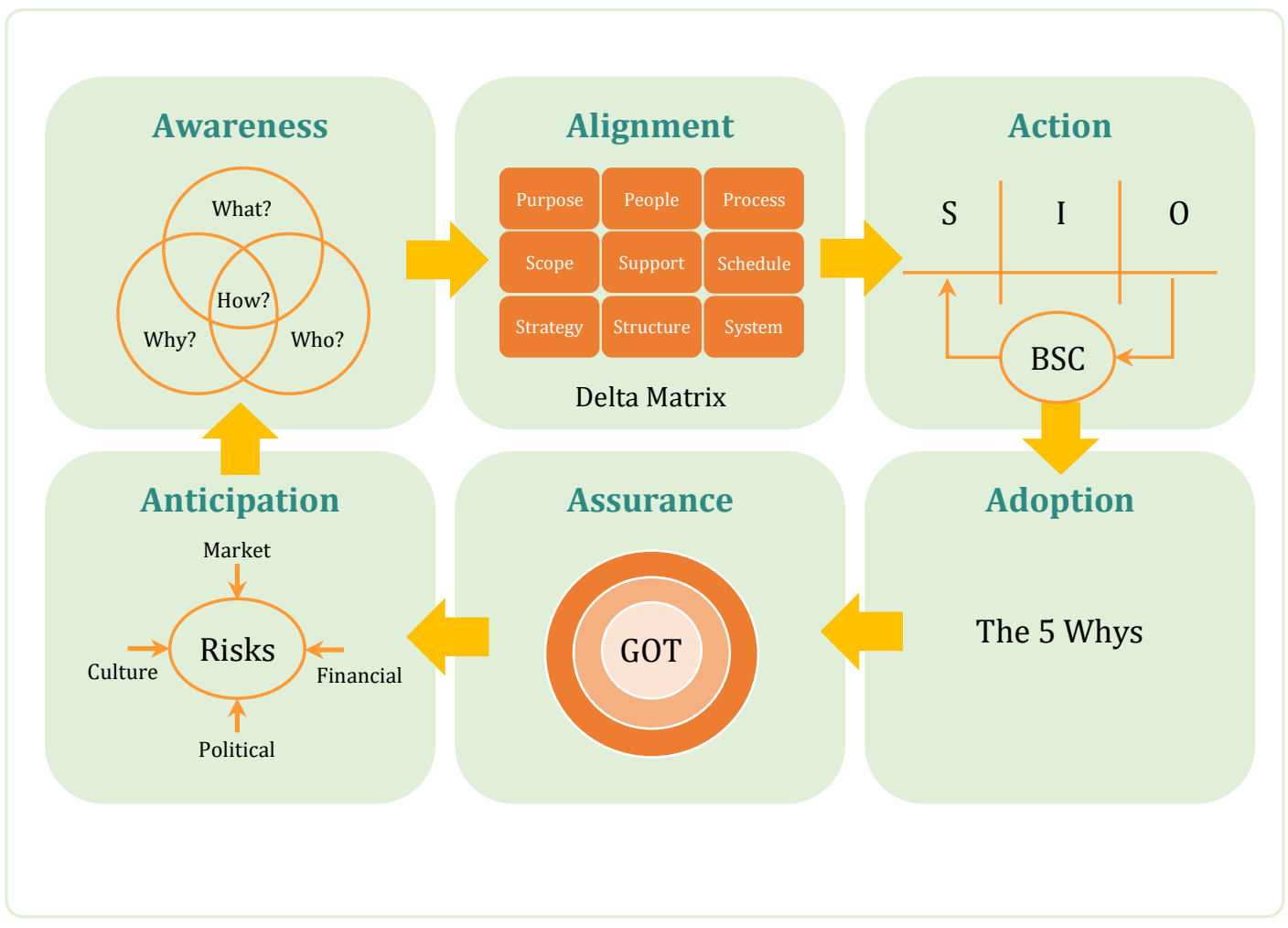

Figure 4: Design thinking applied to IBM method.

A wareness Phase (I need to know what are my strengths and weaknesses)

The self-discovery of every student on the IBM programme has been carried out at the beginning of the third year of a four-year honour's degree. The first two years are taken up with general management studies. Their first contact with the lead author is at the beginning of the third year, when he delivers the following four IBM specialisation modules: Introduction to International Business Management and International Marketing Management in Year 3; and Global Strategic Management and Multinational Enterprise \& Government in Year 4.

Each module is taught over 14 weeks, spread over four months, with 42 hours of applied teaching and learning through project-based action learning. During the period of the research project (2006 - 2018), the lead author visited the university on a fortnightly basis and alternate lessons were allocated for team presentation on a contemporary topic or actual event that needs creative and innovative solutions - for example, the trade war between China and the United States of America: what is the impact on the Indonesian economy?

Each team is given a specific industry to be analysed and discussed for the IBM module. In total, there are six real-world, project-based case analyses focusing on current events using concepts and theories taught during class. Students are encouraged to think 'unboxed' by searching for the latest concepts and information to support their delineation. 
There is a mid-term and a final-term exam using contemporary research articles that apply to real-world case studies. The students need to be aware of their learning style (Kolb, 2017) and their strengths and weaknesses within Belbin's (2010) nine team roles so that they can identify areas for individual improvements and perform better as a team. In the example provided in Figure 6, the student scored most as a reflector which implies that before engaging in action, she makes sure that she has enough knowledge to proceed. She is thus more of a pragmatist than an activist.

On the other hand, when involved in a project, students who display their leadership role make decisions (shaper), chair meetings and get things done through others (coordinator), ensure that all documentation is duly completed (completer/finisher), avert friction when the team is moving towards a conflict situation (team worker) and at the same time evaluate the quality of the work (resource investigator). The profiling of the nine team roles is based on the work of Belbin (2010; see Figure 7). Further, the action learning balanced scorecard is introduced and each team must identify what they have learnt at the end of every presentation (see Figure 5).

\begin{tabular}{|c|c|c|c|c|c|c|c|}
\hline $\begin{array}{l}\text { Project-based } \\
\text { Action Learning }\end{array}$ & $=\begin{array}{c}\text { Rote } \\
\text { Learning }\end{array}$ & + & $\begin{array}{c}\text { Questioning } \\
\text { Insight }\end{array}$ & + & Implementation & + & Reflection \\
\hline $\begin{array}{c}\text { How much } \\
\text { have I learnt? }\end{array}$ & What? & & Why? & & $\begin{array}{l}\text { How? } \\
\text { Who? } \\
\text { When? }\end{array}$ & & Where? \\
\hline
\end{tabular}

\section{Figure 5: Project-based action learning paradigm.}

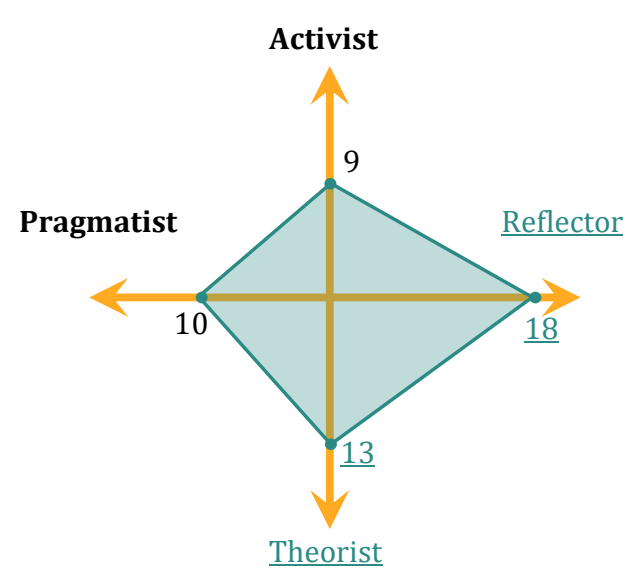

Figure 6. Example of a student learning style (Kolb, 2017).

Figure 6: Example of a student learning style roles

(Kolb, 2017).

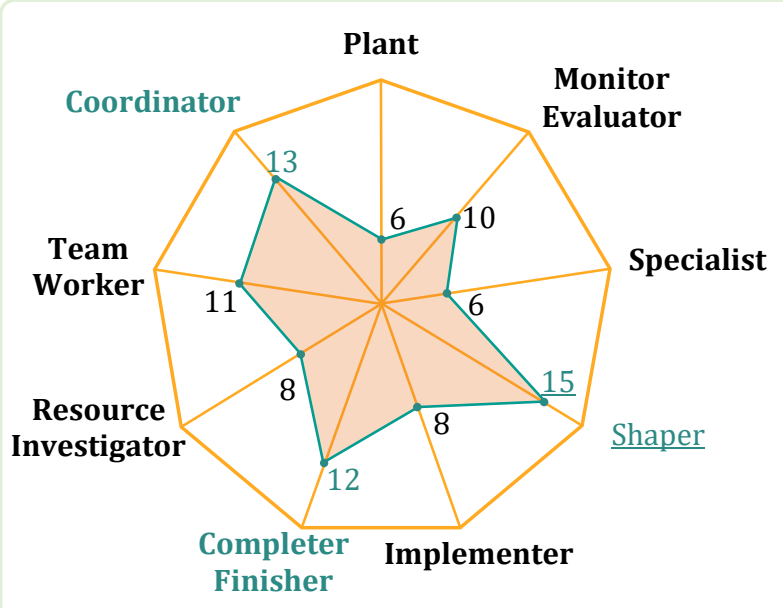

Figure 7. Example of a student Belbin's 9 team roles (Belbin, 2010).

Figure 7. Example of a student Belbin's 9 team (Belbin, 2010). 
The primary objective is to make sure the students have reflected on what they have learnt from each presentation. The rationale is to improve their design thinking skills. Design thinking consists of engaging the whole brain to look at a topic or issue being evaluated, applying four types of reinforcing and intertwined competencies:

- Holistic thinking - to integrate concepts, theories, and solutions to achieve clarity in planning.

- Systems thinking - to implement projects with the right people, process and tools for effective control using the right key performance indicators (KPIs) to measure the successful execution of the strategy. Strategy is better managed and controlled by converting it into projects.

- Critical thinking - to innovate as an outcome of effective decision-making by choosing the right alternatives.

- Lateral thinking - to improve continuously as an outcome of evaluating from six different perspectives (de Bono, 1985).

The elements in applied teaching in the IBM module need to be integrated and connected. The clarion test for this is a template called the Delta Matrix (see Figure 8). The Delta Matrix as a wholistic approach applied to IBM has nine design thinking elements adapted from Bartlett and Ghoshal (1994, 1995a, 1995b): Purpose (Why?) of studying IBM; scope (What? and What Is not?) of IBM; strategy (How to get there?) of IBM for doing business regionally, internationally, and globally; people (Who?): IBM stakeholders who can influence the success or failure of its strategy; support (Where resources are needed?) of IBM is available at the right time, place and quantity; structure (How to organise to optimise?) of IBM for faster, better, supreme execution capability; process (How to implement?) of IBM for sustainable competitive edge to beat the competition; schedule (When to implement?) of IBM for short-, mid-, and long-term business results; and system (How to measure?) of IBM using an appropriate balanced scorecard with the right key performance indicators (KPIs). 


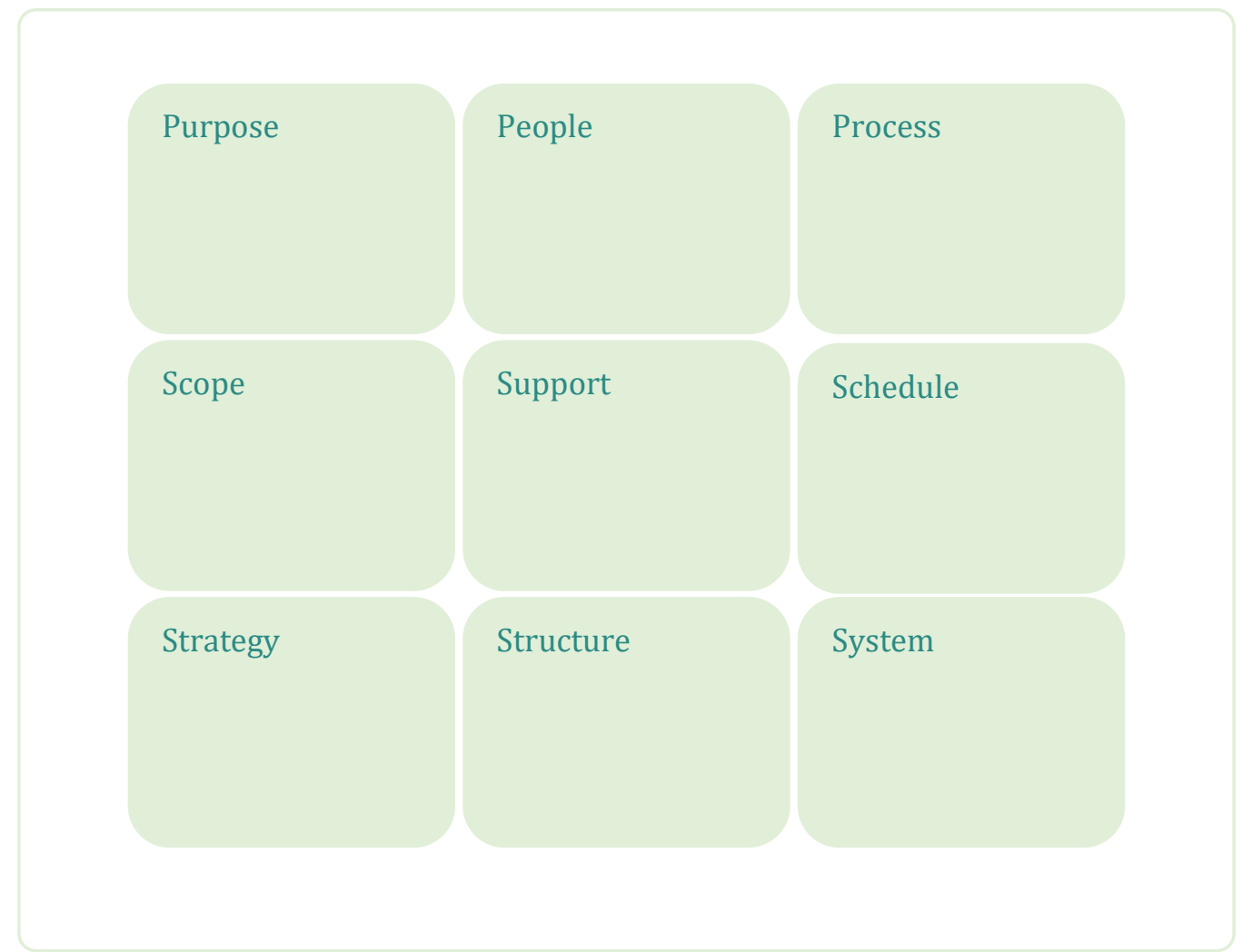

Figure 8: Delta Matrix (See Appendix for Summary of IBM elements.

The first step is to ensure a vertical fit of the three elements by aligning purpose-scopestrategy; people-support-structure; and process-schedule-system:

- Strategy is to achieve the purpose of the business/project and focus on its scope to accomplish the specific goals/objectives/deliverables.

- People (stakeholders) are organised in the right organisation structure to achieve optimum performance with adequate support, i.e. resources (money, manpower, machine, material, method) including quality time, conviction and commitment from senior management.

- Process is implemented at the right time/schedule to meet the delivery promise and is measured with the right balanced scorecard system for monitoring and control (learning and growth, internal business processes, customer satisfaction, and sustainable financial performance).

The next step is to ensure a horizontal fit of the three elements by aligning purpose-peopleprocess, scope-support-schedule, and strategy-structure-system:

- Purpose of business mission, goals and objectives can only be attained by engaging the right people who implement the right process and are equipped with the right tools/technology.

- Scope cannot be overly ambitious and should stay focused on 'what is', and away from 'what is not', the core business and the distinct competence of the organisation. Senior management needs to recognise the importance of setting the right priorities, support and 
commitment to providing resources and quality time to track and manage the project by adhering to the promised milestone schedule for project deliverables. If management is not convinced about this, the project will be at risk of underperforming.

- Strategy needs the right organisation structure to ensure effective and efficient execution. As advocated by Chandler (1962), "structure follows strategy". In some world-class organisations, key projects have project managers and team members reporting directly to the CEO using an informal organisation structure called "projectised structure" (PMI, 2017), which will be dissolved once the project is successfully completed. A strategy is only a plan. The strategy is converted into projects for its successful execution to achieve the required business results. Without an appropriate balanced scorecard system with the right key performance indicators (KPIs), it is difficult to monitor and control the successful execution of the strategy (Kaplan \& Norton, 2008).

Successful execution of a strategy is measured by the business value-add from employees, the overall productivity of internal business processes, customer satisfaction and retention, and sustainable financial performance. The learning and growth of employee competence must be ascertained, otherwise, it will lead to complacency which will erode competitiveness. Using the Delta Matrix as a template and tool, holistic thinking ensures that key elements of the knowledge areas have a good fit (Teng \& Chan, 2018). The final audit is to ensure a diagonal fit of the three elements, purpose-support-system and strategy-support-process, for tenacity.

- Purpose, support and system must also be aligned for their diagonal fit. The business goals, objectives and targets (purpose) must be matched by the maximum utilisation and optimisation of resources (support) to achieve best cost, best performance and/or best solutions. There must be a proper feedback and control system with the right balanced scorecard to measure the right KPIs, taking into account people (learning and growth), process (continuous improvement through innovation) (how to transform expensive and complex products, services, and solutions into simple and affordable ones), customer expectation and experience (customer loyalty and retention through tracking and managing the customer happiness index), and sustainable financial performance (divesting those products and services that are uncompetitive before it is too late).

- Strategy, support and process must also be aligned for their diagonal fit. The end game of strategy is to implement a cost-effective and efficient process for optimisation of resources. To garner continuous support from investors, the winning order objectives are cost, quality, speed, reliable delivery promise, and flexibility advantage. In the IBM module, the emphasis is on transforming a customer-centric design thinking strategy into an action advantage to minimise the strategy-execution gap, i.e. fostering execution capabilities regionally, internationally, and globally.

Alignment Phase (We understand what is the core competence of IBM students)

A core competence has been described as unique, scalable, and hard to emulate (Hamel, 2007). Hence, the IBM students have to focus on building up their whole-brain thinking 
skills, i.e. wholistic thinking. This is developed from the design thinking concept of transforming complex and sophisticated ideas, concepts and models into simple and practical ones, by applying holistic, systems, critical, and lateral treatment to develop the individual, team and organisational competence in the ability to integrate, implement, innovate and improve continuously for a high-performance culture. This can be a win-win-win paradigm shift (the way we think, work and behave) for students, faculty, department, and the university. The maturity of an organisation depends on the accelerated learning among its stakeholders. Wholistic thinking can be used as the common thread that bridges the gap between concept and competence with the right connections, for instance via the Delta Matrix (Chan, 2018).

From the second module onwards, the students can better appreciate the usefulness of case study analysis, using the wholistic thinking approach coupled with project-based action learning. This enhances their chances in national competitions in Indonesian universities. For example, the cohorts in 2007 and 2008 won first prize in the National Nokia Marketing Award, came in first in Indonesia's Strategy for Tourism and Hospitality Competition, and won the National Essay Award in Doing Business Regionally, Internationally and Globally. Since 2010, Petra's IBM graduates have managed to secure entry into Financial Times Top 100 MBA programmes like the ones offered by Australia Graduate Business School (UNSW), Melbourne Business School, London Business School, Erasmus, Nanyang Technological University, or Warwick. In addition, the Petra "Wholistic Team" won the prestigious CIMB Group competition for ASEAN region students who have talent and technological innovation to provide solutions to the challenges of the banking world in the fourth industrial revolution.

For the second module (International Marketing Management), students undergo additional profiling tests for "Big Five Personality Traits" and the "General Entrepreneurship Model" to get a clearer picture of their flair for management and entrepreneurship (see Figure 9 for an example of personality traits and Figure 10 for an example of a general entrepreneurship model). Every student has to combine the learning style, nine team roles, five personality traits, and the general entrepreneurship model. They then need to compile an action learning report in video format and be coached by a lecturer to determine the preferred industrial attachment or internship - local or overseas, and company type. Every student video will be placed on YouTube for viewing by prospective employers. 


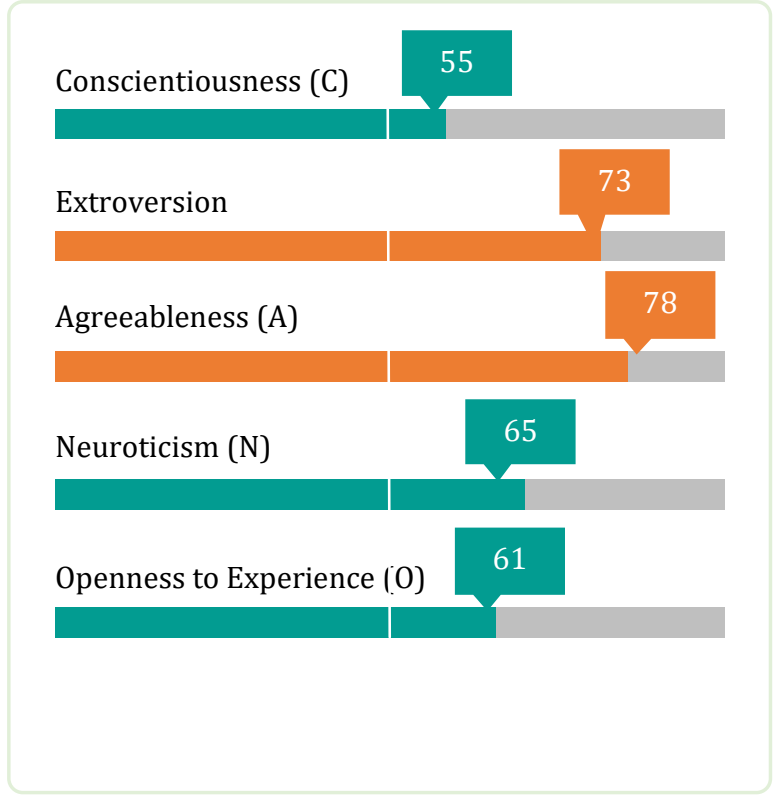

Figure 9: Example of a student personality trait entrepreneurship model.

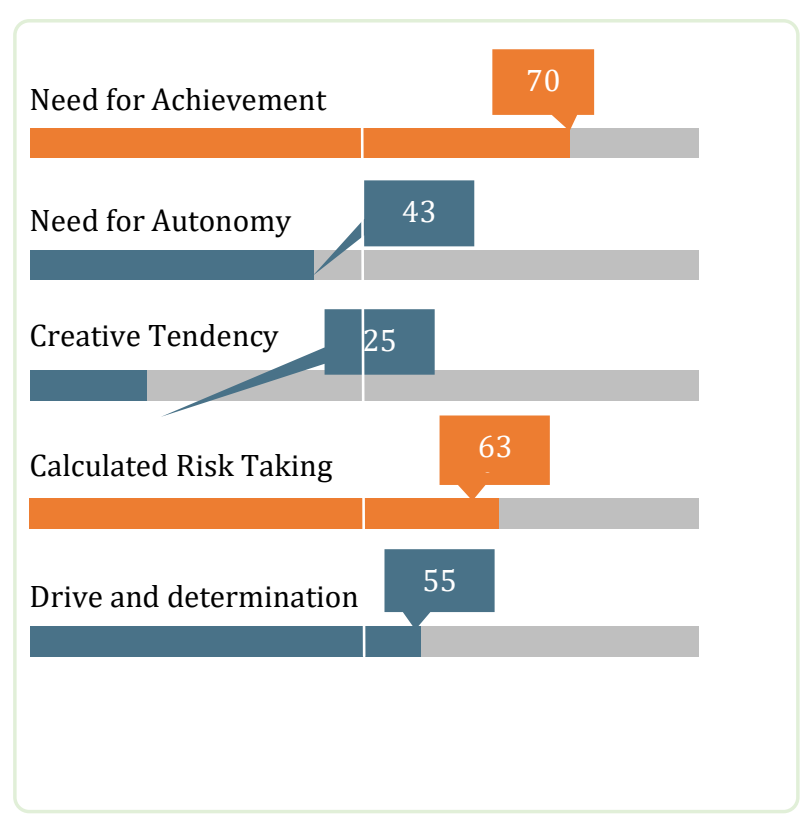

Figure 10: Example of a student general.

Figures 9 and 10 provide examples from the same student who had completed the learning style and nine team roles profiling tests (see Figures $6 \& 7$ ). This student has strong presentation skills, and she also practises using words that work, i.e. keeping sentences succinct, having a positive attitude towards constructive criticism and showing a willingness to change by seeking coaching and mentoring from trusted advisors and lecturers. She also works hard and focuses on critical activities that reap maximum benefits. Indeed, her 20minute video recording based on the profiling analysis of herself and the project-based action learning paradigm on lessons learnt was the best in class for her cohort. She has a flair for entrepreneurship, and is highly motivated for achievement, which is supported by her willingness to take calculated risks, determination to succeed, and desire for autonomy. Her only weakness is her relative lack of creative thinking. This handicap could be addressed with a positive mindset and prudent project-based action learning during her thesis. Indeed, she managed to win a scholarship sponsored by an Indonesian conglomerate.

The students are required to practise the four types of thinking skills (de Bono, 1985) for all assignments, mid-term and final term exams. Initially, they may be resistant to this new frontier of thinking processes. As they pass through the four semesters with the lead author, they can also apply the concept, competence, and connections of whole-brain thinking to other subjects that are taught during the third and fourth year of their honours degree.

Action Phase (We can see the benefits of synthesising the four kinds of thinking abilities)

The Global Strategic Management (GSM) module is not easily understood by students who have no real-life business experience. However, after applying the four kinds of design 
thinking skills (de Bono, 1985), students' ability to synthesise information for in-depth analysis has enabled them to come up with pragmatic solutions. The S-I-O (Strategise Implement - Operate) model has been developed to measure the successful execution of strategy by converting it into a portfolio of prioritised programmes and projects for effective implementation to attain the business results - to be monitored and controlled using an enterprise balanced scorecard.

The Hourglass model (Figure 11) was developed by Petra students (Chan, 2017b). The lead author's GSM students organised four colloquia that were open to academics from other departments, covering contemporary knowledge areas from Strategic Global Management, International Marketing, International Business Management, and Multinational Enterprise and Government.

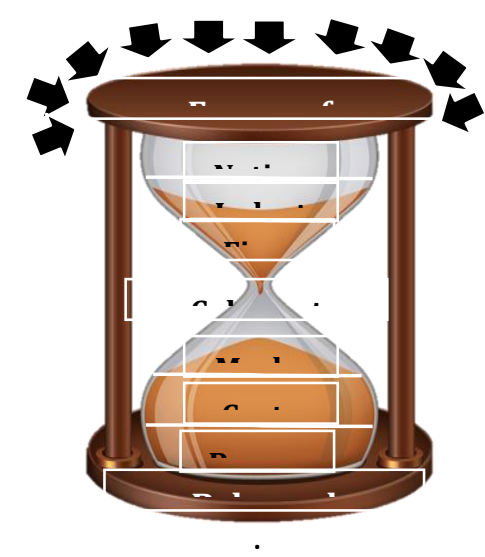

Figure 11: Hourglass model.

The project-based action learning equation needs to satisfy four criteria: original contributions to workplace learning; identification and design of innovative solutions; implementation of those solutions; and assessment of their effectiveness.

\section{Adoption Phase (We want to develop into whole-brain lifelong learners)}

The first batch of IBM students graduated in 2002. In order to have evidence of the programme's usefulness, a survey with 208 respondents was conducted in 2016 for IBM graduates who had over five years of working experience after graduation. The outcome of the survey is shown in Tables 1 and 2. An overwhelming percentage of the respondents perceived 'wholistic thinking' to be of practical value. They endorsed the concept of developing the left brain for analytical abilities and the right brain for holistic abilities, leading to the need to use the whole brain for innovation and effective decision-making. 
Table 1: Survey results (Part 1) : in appendix

Table 2: Survey results (Part 2) : in appendix

Assurance phase (We will excel and become role models for other learners in other institutions of higher learning)

Testimonials are used as an additional primary source in this research. They are important because it is the learners who convey their affirmation as to whether they are respected by other peers or stakeholders who can benefit from wholistic thinking. Of the many testimonials received over the past ten years, the extract below is particularly reaffirming:

"I've gone through MBA studies at two of the world's premier business schools. There is no doubt to me anymore that Dr. Chan set a very high bar for his students at IBM Petra. Not only have his... lectures helped me to win academic competitions and to excel academically, they have also built the necessary thought processes in my mind to think way beyond my years of experience. While there are other business professors that deliver similarly high-quality materials as Dr. Chan, the skills he taught to make me a holistic, systematic, and critical thinker have been simply unparalleled by any others... The skills Dr. Chan taught me are still relevant even after almost a decade. Information and knowledge will be obsolete after some time, but a sound thought process will never be".

There have been many other testimonials emanating from the IBM programme. In accordance with the process described in the Methodology section, we are now discussing the three main themes that we inductively generated.

\section{Wholistic thinking (encompassing critical and holistic thinking)}

First, the graduates' capability for critical and holistic thinking was derived from our analysis. In terms of holistic thinking, the graduates assessed themselves to be able to innovate by using essential decision-making skills, leading to improved efficacy and efficiency. Critical thinking encompasses the cognitive abilities to integrate concepts, theories, and solutions to achieve a desirable outcome. The collated graduate reflections revealed that they honed critical and holistic thinking in their ability to conceptualise theories, execute actionable and measurable plans, and were able to problem-solve "in a faster..., better... and a smarter way" (to cite one of the graduates). The IBM graduates reflected on their learning journey and the quotes below present selected insights gained after attending the IBM programme:

"Studying the Wholistic Approach is very beneficial for me. With this great concept of thinking, we can solve complex problems and attain effective business results. A very pragmatic approach that is unique" (Human Resources Director, PT HM Sampoerna Tbk.). 
"We can analyse problems holistically, and critically select pragmatic strategy for filling the knowing and doing gap, using the tools of wholistic thinking for integration, innovation, and systematic implementation of the solutions".

"It helps me to think critically what may become the main problem, deeply understand what are the inputs to be transformed into the targeted output (action learning process)" (Marketing Director, PT Sopanusa).

\section{Structured thinking}

The second inductively generated key theme is structured thinking. It encompasses cognitive skills involving breaking down complex problems, the ability to recognise patterns and identify important information while ignoring unrelated or irrelevant detail, and finally sequencing the problems logically and orderly for easy understanding, thereby achieving a flow (Andrian \& Hikmawan, 2021). Many IBM graduates discovered that after attending the course, they were able to solve their problems with more ease, employ strategies systematically, which in turn provided them with 'flow' in their learning and train of thoughts. Below are some examples of pertinent reflective statements by IBM graduates:

"I can plan my business strategies, implement those strategies, and control the strategies better in my work-life" (COO, PT SMART).

"It helps me to expedite the progress of my dissertation. The thought process makes it easy to construct my dissertation".

"It helps business people to analyse through a wholistic perspective and they are able to generate strategic and measurable decisions" (SVP, Bank Permata).

"I think it is about seeing the bigger picture and after that the details. Then arrange it systematically and logically to achieve supreme performance" (Engagement Manager, McKinsey).

\section{Project management skills}

In the final theme, project management skills were identified. They refer to the process of attaining project objectives with limited resources, without adversely disturbing routine operations (Munns \& Bjeirmi, 1996). The IBM graduates reflected on their learning journey and elaborated on their successes. Many were able to achieve project objectives with minimal assistance by applying a collection of tools and techniques gained during their IBM studies. Many graduates also felt that the project management skill set acquired during their studies equipped them to work more efficiently and meticulously. The quotations below illustrate the continuous improvement of the graduates:

"Not to miss any detail in the whole process of planning, integration, execution, and 
control in doing every project".

"I have learned to make better decisions, and then implement and control them in order to be successful".

"It makes the work faster, better, smarter, faster, better, smarter, with continuous improvement".

In the final module of the last semester, Multinational Enterprise \& Government, every student is required to produce a 15-minute video detailing what they have learnt from the first to the fourth module using the project-based action learning equation, and the five profiling tests that give an indicator of their management, leadership and entrepreneurship style. Figure 12 shows the four types of power for self-development. Each student provides an action plan for short-term achievements (up to three years after graduating), mid-term career advancement (up to six years after graduating), and long-term professional goals (up to ten years after graduating). The fact remains that though many plans have failed, more have failed to plan. The essence of a plan is the outcome of a thought process. It must be transformed into activities with process ownership for business results.

\section{Self-Awareness \\ (Intellectual Capital)}

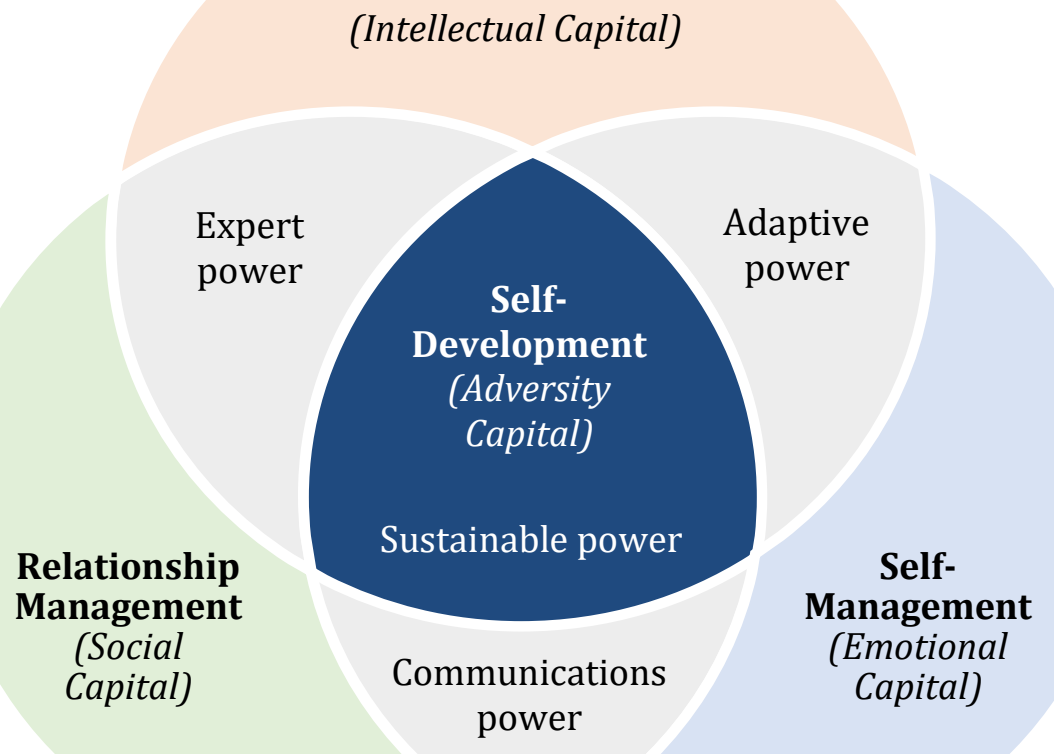

Figure 12: Self-development power. 
Anticipation Phase (We have to work around the limitations and implications of projectbased action learning)

Project-based action learning and design thinking for a wholistic approach to attain accelerated learning is not a panacea. It is a good strategic intent to improve on the current approach to teaching management, leadership, and entrepreneurship. The concept of disruptive innovation shows that there is no best way but always a better way. Disruptive innovation is all about transforming expensive and complex products and services into simple and affordable ones (Christensen, 1997). After that comes 'disruptive thinking'. When applied to learning and teaching, the lead author has started to introduce a pragmatic approach using the concept of disruptive thinking (see Figure 13 ).

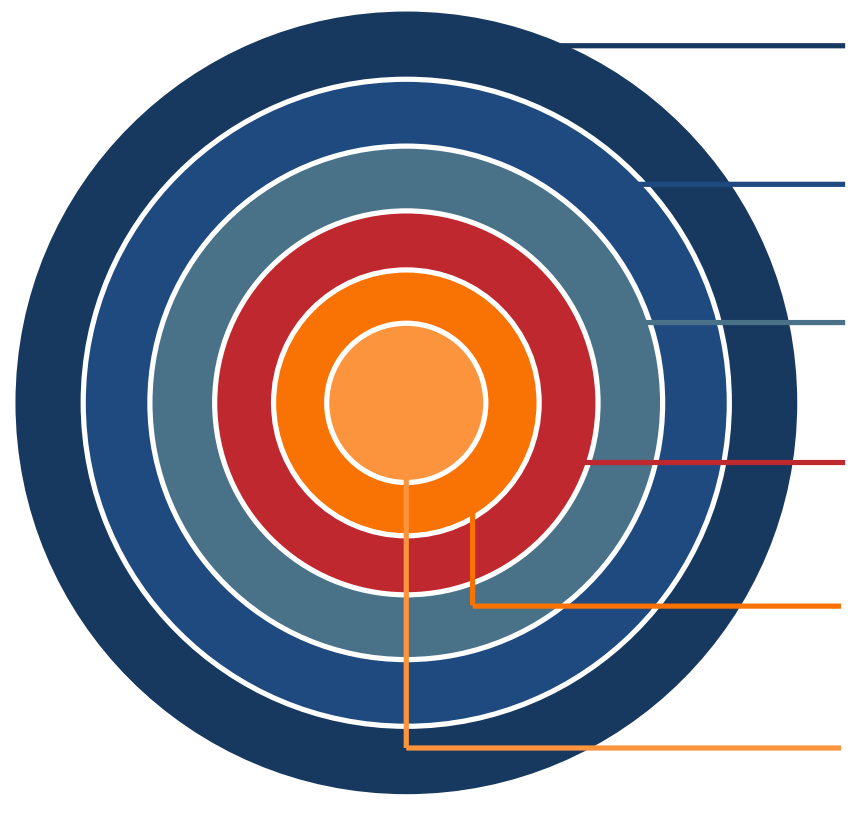

Expert Power

(Reinvent)

Adaptive Power

(Rethink)

Execution Power

(Reengineer)

Communicative Power

(Redesign)

Response Power

(Redefine)

Stamina Power

(Rejuvenate)

Figure 13: Onion diagram of disruptive thinking.

In management, leadership and entrepreneurship (which in the era of digital transformation in Industry 4.0 will evolve into technopreneurship), most important is what works - the basic concept of artificial intelligence is about deep learning using real experiences (Lee, 2018). This is espoused by the late Peter Drucker (2008), the father of modern management, entrepreneurship and innovation. The gap between theory and practice must be bridged, otherwise, management theories can be ten to 20 years ahead of time, while the practice is still following the old ways until the organisation enters a crisis (Sutton, 2012). 


\section{- 4 CONCLUSION}

In essence, this article focuses on teaching students how to think better, faster, and smarter so that they can achieve more through accelerated learning (as an outcome of project-based action learning). Knowledge is accumulated from a concerted effort to learn and in tandem with what is being taught. It cannot be left to Senge's (1990) old concept of a learning organisation where everyone is assumed to take an active part in learning and is committed to self-actualisation. To be sure, it is the responsibility of every student to be aware of their strengths and weaknesses at the beginning of their journey towards self-development.

Five profiling tests were implemented and students were required to craft an action plan that stretched over a ten-year period, so that whatever they have learnt was related to accomplishing their individual career goals. Thus, they were developing expert power (based on intellectual capital obtained from the course of study), connection power (based on social capital through networking with key stakeholders), adaptive power (as an outcome of emotional capital through project-based action learning to enhance their leadership, management and 'technopreneurship' abilities), and sustainable power (with stamina to remain resilient, and adversity capital to last for the ten-year action career plan). In a similar vein, Christensen (2012) has emphasised the need for self-discovery to think. We may not be able to change the world of applied learning and teaching, but we can change how people think to change the future of education and bridge the gap between teaching and learning.

There are limitations to this study, as they focused on one professor's (the lead author) teachings, one programme (International Business Management) at one university (Petra Christian University) in one country (Indonesia) during a certain period (2006 - 2018). On the plus side, the whole eligible population was surveyed (rather than sampled) over an extensive time period longitudinally, and, typical for action research, multiple sources (including mixed-method research) were employed.

There are opportunities for future research. Due to the coronavirus pandemic, travel between Singapore (where the lead author is located) and Indonesia was rendered impossible from early 2020 onwards, and hence face-to-face teaching by the lead author did not take place. It could be interesting to compare the effectiveness of the IBM programme at Petra pre- and intra-pandemic - and hopefully, in the not too remote future: post-pandemic. Whilst action research is notoriously difficult to replicate, it would not be impossible to use other faculty at different universities with a similar approach and compare the experiences. Finally, further graduate surveys to further track the progress of the IBM graduates would be apt.

\section{ACKNOWLEDGMENTS}

We thank Joey Crawford (University of Tasmania) for his valuable comments on an earlier draft. Also, the research assistance of Tammy Tan and Yasmin Liyana is acknowledged with gratitude. 
Journal of Education, Innovation and Communication, sponsored by the Communication Institute of Greece

\section{REFERENCES}

Abraham, S. (2012). Work-applied learning for change. AIB Publications Pty Ltd.

Andrian, R., \& Hikmawan, R. (2021). The importance of computational thinking to train structured thinking in problem solving. Jurnal Online Informatika, 6(1), 113-117.

Barkley, S., Bottoms, G., Feagin, C. H., \& Clark, S. (2001). Leadership matters: Building leadership capacity. Southern Regional Education Board, Atlanta, GA. https://files.eric.ed.gov/fulltext/ED464391.pdf

Bartlett, C. A., \& Ghoshal, S. (1994). Beyond strategy to purpose. Harvard Business Review. https://hbr.org/1994/11/beyond-strategy-to-purpose

Bartlett, C. A., \& Ghoshal, S. (1995a). Changing the role of top management: Beyond systems to people. Harvard Business Review. https://hbr.org/1995/05/changing-the-role-of-top-management-beyond-systemsto-people

Bartlett, C. A., \& Ghoshal, S. (1995b). Changing the role of top management: Beyond structure to processes. Harvard Business Review.

Belbin, M. R. (2010). Team roles at work (2nd ed.). Amsterdam: Taylor \& Francis.

Bonk, R. J., Kefalaki, M., Rudolph, J., Diamantidaki, F., Rekar Munro, C., Karanicolas, S., Kontoleon, P., \& Pogner, K. H. (2020). Pedagogy in the Time of Pandemic: From Localisation to Glocalisation. Journal of Education, Innovation, and Communication, 2(SI1), 17-64.

Braun, V. \& Clarke, V. (2006). Using thematic analysis in psychology. Qualitative Research in Psychology, 3(2), 77-101. https://doi.org/10.1191/1478088706qp063oa

Butler-Henderson, K., Crawford, J., Rudolph, J., Lalani, K., \& Sabu, K. M. (2020). COVID-19 in Higher Education Literature Database (CHELD V1): An open access systematic literature review database with coding rules. Journal of Applied Learning \& Teaching, 3(2), 11-16. https://doi.org/10.37074/jalt.2020.3.2.11

Butler-Henderson, K., Tan, S., Lalani, K., Mandapam, S. K., Kemp, T., Rudolph, J., \& Crawford, J. (2021). Update of the COVID-19 Higher Education Literature Database (CHELD v2). Journal of Applied Learning \& Teaching, 4(1), 134-137. https://doi.org/10.37074/jalt.2021.4.1.22

Carter, L., Ulrich, D., \& Goldsmith, M. (Eds.). (2012). Best practices in leadership development and organization change: How the best companies ensure meaningful change and sustainable leadership (Vol. 18). John Wiley \& Sons.

Chan, K. C. (2017a). Project-based action learning. TWAN Publishing.

Chan, K. C. (2017b). Doing business regionally, internationally, and globally. TWAN Publishing.

Chan, K. C. (2018). Design thinking: Management, leadership, technopreneurship. TWAN Publishing.

Chandler, A. D. (1962). Strategy and structure: Chapters in the history of the industrial empire. Academia.

Christensen, C. M. (1997). The innovator's dilemma. Harvard Business School Press.

Christensen, C. M. (2012). How will you measure your life? HarperCollins Publishers.

Crawford, J., Butler-Henderson, K., Rudolph, J., Malkawi, B., Glowatz, M., Burton, R., Magni, A. P., \& Lam, S. (2020). COVID-19: 20 countries' higher education intra-period digital pedagogy responses. Journal of Applied Learning \& Teaching, 3(1), 9-28. https://doi.org/10.37074/jalt.2020.3.1.7

de Bono, E. (1985). The direct teaching of thinking as a skill. Education, 2(1), 1-8.

De Wit, H., Hunter, F., Howard, L., \& Egron-Polak, E. (2015). Internationalisation of higher education. Directorate-General for Internal Policies, Policy Department B: Structural and Cohension Policies, Culture and Education, European Parliament.

Gay, L. R., \& Airasian, P. (2003). Education research (2nd ed.). Prentice Hall. https://hbr.org/1995/01/changing-the-role-of-top-management-beyond-structure-to-processes

Hamel, G. (n.d.). The future of management. https://hbr.org/product/the-future-of-management/2505-HBKENG

Kaplan, R. S., \& Norton, D. P. (2008). The premium execution: Linking strategy to operations for competitive advantage. Harvard Business Review Press.

Koch, R. (1999). The 80/20 principle: The secret to achieving more with less (Reprint edition). Currency. 
Koch, R. (2014). The 80/20 principle and 92 other powerful laws of nature: The science of success (New edition). London: Nicholas Brealey.

Lee, K.-F. (2018). AI superpowers: China, Silicon Valley, and the New World Order. Houghton Mifflin Harcourt.

Litamahuputty, V. (2015, October 15). UK Petra dinilai masih terbaik dari Sejumlah PTS di Indonesia. Berita Satu, https://www.beritasatu.com/archive/315449/uk-petra-dinilai-masih-terbaik-dari-sejumlah-pts-diindonesia

Marquardt, M. (2011). Optimizing the power of action learning: Real-time strategies for developing leaders, building teams and transforming organisations (2nd ed.). Boston, Mass: Nicholas Brealey.

Maulani, G. A. F., \& Hamdani, N. A. (2019). The influence of information technology and organizational climate on the competitiveness of private universities in Indonesia. International Journal of Recent Technology and Engineering, 8(1S), 142-145.

Mettetal, G. (2002). The what, why and how of classroom action research. Journal of the Scholarship of Teaching and Learning, 2(1), 6-13.

Munns, A. K., \& Bjeirmi, B. F. (1996). The role of project management in achieving project success. International Journal of Project Management, 14(2), 81-87.

National Training Laboratories Institute for Applied Behavioral Sciences (2005). The learning triangle: Retention rates from different ways of learning. Bethel.

Nieto-Rodriguez, A. (2016). How to prioritise your company's projects. Harvard Business Review. https://hbr.org/2016/12/how-to-prioritize-your-companys-projects

Revans, R. (2011). ABC of action learning (1st ed.). Farnham: Routledge.

Senge, P. M. (1990). The fifth discipline. The art \& practice of learning organization. Doubleday Currency.

Senge, P. M. (2014). The fifth discipline fieldbook: Strategies and tools for building a learning organization. Currency.

Slevin, E., \& Sines, D. (1999). Enhancing the truthfulness, consistency and transferability of a qualitative study: Utilising a manifold of approaches. Nurse Researcher, 7(2), 79-97.

Sutton, R. I. (2012). Good boss, bad boss: How to be the best... and learn from the worst. New York, NY: Business Plus.

Teng, M., \& Chan, K. C. (2018). Paradigm shift in humanities learning journey. In Learning geography beyond the traditional classroom (pp. 101-108). Springer, Singapore.

Top Universities. (2021). Petra Christian University. https://www.topuniversities.com/universities/petra-christian-university

UK Petra raih predikat PTS terbaik di Indonesia. Jawa Pos (2017, April 17). https://www.pressreader.com/indonesia/jawa-pos/20170417/281797103866078

uniRank. (2021). Petra Christian University. https://www.4icu.org/reviews/universitiesenglish/2202.html

Von Hippel, P. T., \& Hofflinger, A. (2021). The data revolution comes to higher education: Identifying students at risk of dropout in Chile. Journal of Higher Education Policy and Management, 43(1), 2-23.

Wills, G. (1993). Your enterprise school of management. Bradford, England: MCB University Press.

Zuber-Skerritt, O. (2017). Conferences as sites of learning and development: Using participatory action learning and action research approaches (1st ed.). Routledge, London, New York. 


\section{APPENDIX: DATA MATRIX}

\begin{tabular}{|c|c|c|}
\hline Purpose & People & Process \\
\hline Why? & Who? & Way? \\
\hline Scope & Support & Schedule \\
\hline Is/Is Not? & Where? & When? \\
\hline Strategy & Structure & System \\
\hline $\begin{array}{c}\text { How to } \\
\text { Get There? }\end{array}$ & $\begin{array}{c}\text { How to } \\
\text { Organise? }\end{array}$ & $\begin{array}{c}\text { How to } \\
\text { Measure? }\end{array}$ \\
\hline
\end{tabular}

\section{Explanation of each element of the Delta Matrix}

- The Purpose of IBM is to conduct business outside the home country to survive, stay competitive and take advantage of globalisation forces that create business opportunities. The Scope of IBM covers the management functions of Marketing, Human Capital, Technology, Finance, Operations and Organisation Control in the IB environment. Three Strategies can reduce the complexities of IBM i.e., Standardisation for Economies of Scale, Customisation for Economies of Scope and Integration for Economies of Synthesis.

- The diversity of different People and their culture, defined as Stakeholder Expectations Management, create a different IB environment which requires different types of Support, i.e. Economic Performance, Business Efficiency, Government Efficiency or Infrastructure. To manage across functional and across regional operations, a firm conducting IB needs to adopt a Matrix Organisation Structure.

- The Process of conducting IB involves Market Entry, Business Development and Market Penetration which passes through three phases of Schedule; Market-Driven, Customer-Driven and Process-Driven. Firms may adopt an Ethnocentric, Polycentric, Regiocentric, or Geocentric System to nurture the appropriate organisation culture to cope with the diversity of multi-cultural management in a borderless world. 

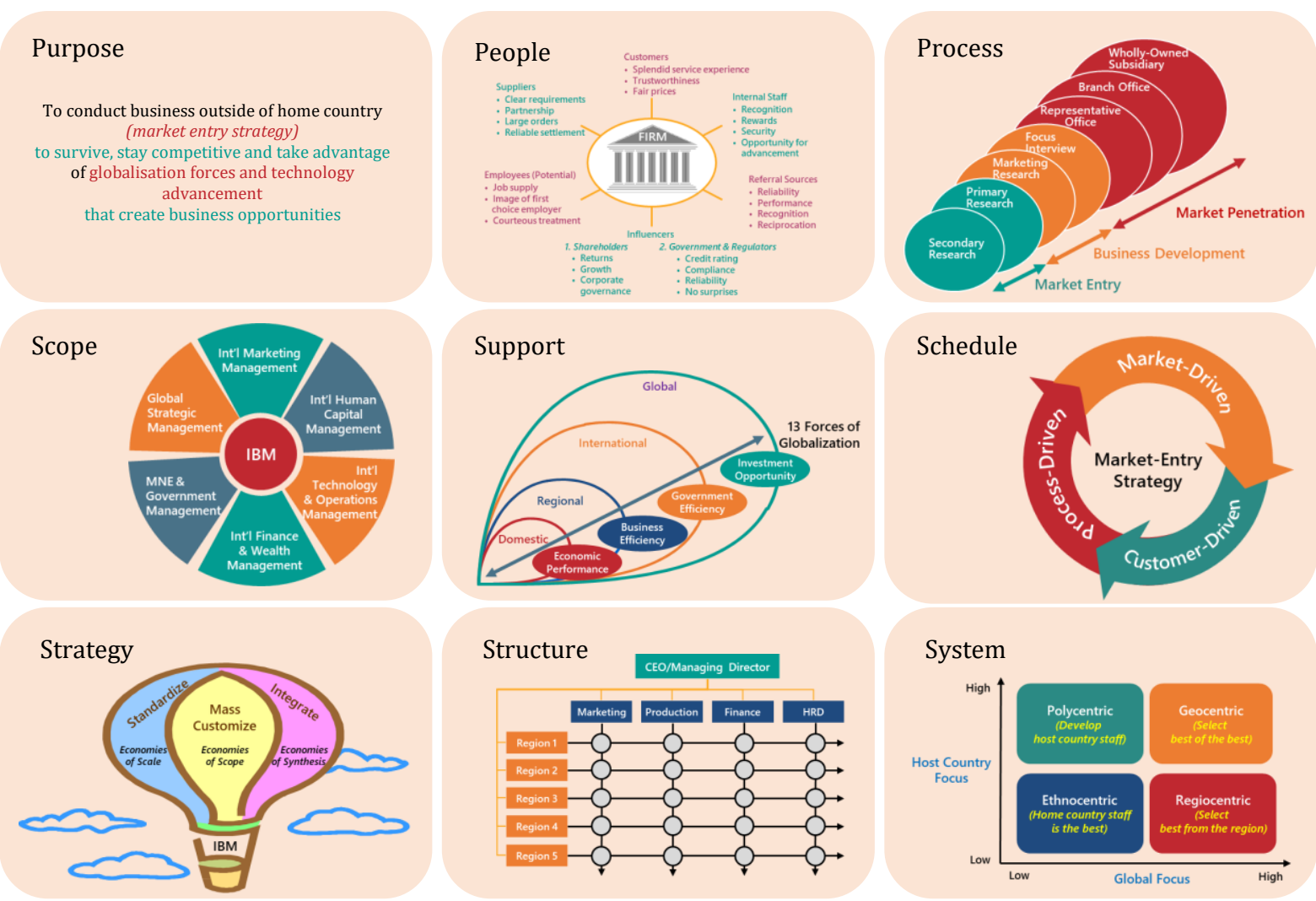

Table 1: Survey results (Part 1)

\begin{tabular}{lc}
\hline Question & "Often" response \\
\hline $\begin{array}{l}\text { How often do you apply holistic thinking in your } \\
\text { work? }\end{array}$ & $64 \%$ \\
How often do you apply systems thinking into your & $64 \%$ \\
work? \\
$\begin{array}{l}\text { How often do you apply critical thinking in your } \\
\text { work? }\end{array}$ \\
$\begin{array}{l}\text { How often do you apply lateral thinking in your } \\
\text { work? }\end{array}$ \\
$\begin{array}{l}\text { Do you agree that holistic thinking helps in } \\
\text { integration of ideas, concepts, strategies, etc? }\end{array}$ \\
$\begin{array}{l}\text { Do you agree that systems thinking helps in } \\
\text { implementation of strategy (after scrutinising from } \\
\text { different perspectives because of holistic thinking)? }\end{array}$
\end{tabular}


Do you agree that critical thinking helps in the $92 \%$ innovation of existing concepts, strategies, redesigning new products/services/solutions?

Do you agree that lateral thinking helps in $91 \%$ improving continuously using the six thinking hats for brainstorming as input to holistic, systems and critical thinking?

Do you agree that only in IBM, our unique learning experience is wholistic thinking?

Do you agree that applying wholistic thinking correctly will help you achieve faster, better and smarter solutions in your work?

Do you agree that wholistic thinking is a concept to be shared with more students, lecturers, working adults, anyone who wants to think differently?

Do you agree that wholistic thinking plus action $89 \%$ learning is truly a powerful process and tool for future competence to be learned by people who wish to perform better?

Do you agree that holistic thinking helps in integration of ideas, concepts, strategies, etc? 
Journal of Education, Innovation and Communication, sponsored by the Communication Institute of Greece

DOI https://doi.org/10.34097/jeicom-3-2-december2021-4

CC BY

Table 2: Survey results (Part 2)

\begin{tabular}{llllll}
\hline Survey assertions & $\begin{array}{l}\text { Not } \\
\text { agree }\end{array}$ & Somewhat agree & Neutral & Agree & Strongly agree \\
\hline $\begin{array}{l}\text { Holistic, systems, critical } \\
\text { and lateral thinking are }\end{array}$ & $1 \%$ & $10 \%$ & $40 \%$ & $50 \%$ \\
important for business \\
performance.
\end{tabular}

This Journal Article is brought to you for free and open access by the double blind reviewed Journal of Education, Innovation and Communication, sponsored by the Communication Institute of Greece. For more information, please take a look at https://coming.gr/journal-of-education-innovation-and-communicationjeicom/ or/and email us at jeicom@coming.gr 